\title{
Influence of puroindoline genotypes on grain characteristics, physico-chemical properties of flour and end-use quality of Korean wheats
}

\author{
Chul-Soo Park ${ }^{1)}$, Chon-Sik Kang'), Young-Keun Cheong ${ }^{1)}$, Woosuk Jung ${ }^{2)}$ and Sun-Hee Woo*3) \\ 1) National Institute of Crop Science, RDA, Suwon 441-857, Korea \\ 2) College of Life \& Environmental Sciences, Konkuk University, Seoul 143-701, Korea \\ 3) Department of Crop Science, Chungbuk National University, Cheong-ju 361-763, Korea
}

\begin{abstract}
Puroindoline genotypes, grain characteristics, physico-chemical properties of flour and end-use qualities of Korean wheat cultivars were evaluated to determine the influence of puroindolines genotypes and to provide on those characteristics. Nine Korean wheat cultivars carried Pina-Dla/Pinb-Dla, fourteen had Pina-Dla/ Pinb-D1b, and three had Pina-Dlb/Pinb-Dla. Pina-Dlb/Pinb-Dla and Pina-Dla/Pinb-Dlb genotypes showed significantly higher 1000-kernel weight and hardness index in grain characteristics, higher flour yield, average particle size, ash and protein content, SDS-sedimentation volume, water absorption and mixing time of mixograph, thickness of noodle dough sheet and lower values in lightness of flour and cookie diameter than Pina-Dla/Pinb-Dla genotype. The Pina-D1b/Pinb-Dla genotype showed significantly higher damaged starch content and water retention capacity than other genotypes. Hardness index of grain was positively correlated with flour yield and average particle size of flour. Those parameters were positively correlated with damaged starch, water retention capacity, SDS-sedimentation volume and water absorption of mixograph, and negatively correlated with lightness of wheat flour. In end-use qualities, thickness and lightness of noodle dough sheet and cookie diameter were correlated with hardness index, milling performances and physical properties. However, bread volume and texture of cooked noodles were not influenced by milling performances and physical properties.
\end{abstract}

Key Words: wheat, puroindolines, hardness, milling, flour, end-use quality.

\section{Introduction}

Grain hardness, either soft or hard, has been often used as a key determinant in differentiating wheat classes because hardness has influences on milling and end-use qualities of wheat (Morris and Rose 1996). Hard wheats generally produce coarser particles of flour and greater number of mechanically damaged starch than soft wheats. Therefore, hard wheat flours are generally used for bread and other yeastleavened food, whereas soft wheats are preferred for pastries, cakes and cookies.

Symes (1965) reported that grain hardness of wheat is controlled by the hardness locus $(\mathrm{Ha})$ located on the short arm of chromosome 5D. Barlow et al. (1973) proposed that the major gene must control the production ofwater-soluble proteins which surround starch granules. Greenwell and Schofield (1986) reported that friabilin, water-soluble 15$\mathrm{kDa}$ protein found in the surface of starch and strongly associated with grain hardness, was identified in soft wheat starch granules. Jolly et al. (1993) reported that friabilin was abundant in all soft wheat starch granules, whereas rare on

Communicated by H. Tsujimoto

Received February 3, 2010. Accepted July 20, 2010.

*Corresponding author (e-mail: shwoo@chungbuk.ac.kr) hard wheat starches and absent in durum wheat.

Two major polypeptides, termed as puroindoline a (Pina) and $\mathrm{b}$ (Pinb), were identified as the major components of friabilin (Blochet et al. 1993, Gautier et al. 1994, Rahman et al. 1994). Genes coding for puroindolines are tightly linked to the $\mathrm{Ha}$ locus on chromosome 5D and probably function together with $\mathrm{Ha}$ locus (Sourdille et al. 1996, Giroux and Morris 1997, 1998). Soft wheats contain both Pina-Dla and Pinb-Dla genotypes, which are designated as the wild type of puroindolines. Up to date, 9 allelic variations at Pina-D1 locus and allelic variations at Pinb-D1 locus in common wheats were reviewed by Morris and Bhave (2008).

Hard wheats carrying Pina-D1b allele showed different effects on milling and end-use qualities from Pinb-Dla genotypes. Pina-D $1 b$ genotypes showed harder grain texture, higher flour yield, protein content, damaged starch, water absorption, color score of noodles and loaf volume of bread and lower lightness and ash content of flour than hard wheats with Pinb-D1b (Giroux et al. 2000, Martin et al. 2001, Nagamine et al. 2003, Cane et al. 2004, Chen at al. 2007). In Korea, wheat breeding has been focused on increasing grain yield and early maturation and about 30 cultivars have been developed with the pedigree method since 1970s. Recently, quality improvement associayed with flour 
and end-use has been received more attention by wheat breeders than ever in Korea. However, the information about influences of puroindoline genotypes on milling performance, characteristics of flour and end-use qualities are not available in Korean wheats. This study was conducted to elucidate the relationships among puroindoline genotypes, grain properties and milling performance, as well as to determine the influence of puroindoline genotypes on physicochemical properties of flour and qualities of pan bread, white salted noodles, and sugar-snap cookies made from Korean wheat cultivars in order to provide useful information for improving wheat quality in Korean wheat breeding programs.

\section{Materials and Methods}

\section{Plant materials}

Twenty six leading cultivars of Korean wheats were harvested at Iksan (Upland Crop Experimental Farm of National Institute of Crop Science, RDA) in 2007. The seeds were sawn on October 20 and cultivated following the standard method of wheat in National Institute Crop Science. Mean temperature was higher $\left(9.7^{\circ} \mathrm{C}\right)$ than that of average year $\left(8.7^{\circ} \mathrm{C}\right)$ and average precipitation was lower $(387.6 \mathrm{~mm})$ than that of average year $(492.0 \mathrm{~mm})$.

\section{PCR conditions for puroindoline genotypes}

Genomic DNA was extracted from $100 \mathrm{mg}$ of young leaf tissue using the Genomic DNA prep kit (Solgent Co., Korea) according to the manufacturer's instructions. The allelic variations for puroindolines were evaluated by the procedure described by Gautier et al. (1994).

\section{Grain characteristics}

Test weight and 1000-kernel weight were measured by Grain Scale (Seedburo Equipment Co., USA) and Seed Counter (Pfeuffer GmbH, Germany), respectively. Hardness index was measured by the single kernel characterization system (SKCS) 4100 (Perten Instruments AB, Sweden) according to the Approved Method 55-31 (AACC 2000).

\section{Milling performances and flour characteristics}

Wheat was milled using a Bühler experimental mill according to AACC Approved Methods 26-10. Two kilograms of wheat were conditioned overnight to reach $15 \%$ moisture content and then milled with feed rate of $100 \mathrm{~g} / \mathrm{min}$ and roll settings of 8 and 5 in break rolls and 4 and 2 in reduction rolls. After milling, flour yield was calculated as the proportion of break and reduction flours to total products and break flour yield was calculated by the proportion of break flours to flour yield.

Distribution of flour particle size was measured by the multi-wavelength laser particle size analyzer LS13320 (Beckman Coulter, Inc., USA). Lightness of flour was measured by Minolta CM-2002 (Minolta Camera Co., Japan) with $11 \mathrm{~mm}$ measurement aperture. Moisture, ash content and water retention capacity of wheat flour were determined according to Approved Methods 44-15A, 08-01 and 56-11. The determination of starch damage content was carried out following the procedure described by Gibson et al. (1992) using an enzymatic assay kits (MegaZyme Pty., Ltd., Australia). The SDS-sedimentation test was performed on a constant protein $(300 \mathrm{mg})$ basis according to the procedure of Baik et al. (1994). Optimum water absorption and mixing time of wheat flour were determined using $10 \mathrm{~g}$ mixograph (National Mfg., USA) according to the approved method, 54-40A (AACC 2000). Dough development was measured by rheofermentometer (Chopin, France) according to the procedure of Czuchajowska and Pomeranz (1993).

\section{Pan bread baking}

Pan bread was baked according to the straight-dough methods described by Finney (1984). The ingredients of baking formula consisted of $100 \mathrm{~g}$ ( $14 \%$ moisture basis) of flour, $6 \mathrm{~g}$ of sugar, $3 \mathrm{~g}$ of shortening, $1.5 \mathrm{~g}$ of salt, $5.0 \mathrm{~g}$ of fresh yeast, $50 \mathrm{mg}$ of ascorbic acid, and $0.25 \mathrm{~g}$ of barley malt (about $50 \mathrm{DU} / \mathrm{g}, 20^{\circ} \mathrm{C}$ ). The dough was fermented in a cabinet at $30^{\circ} \mathrm{C}$ and $85 \%$ relative humidity for 70 minutes with two punches and a proof period of $60 \mathrm{~min}$, and then baked at $210^{\circ} \mathrm{C}$ for $18 \mathrm{~min}$. Bread loaf volume was measured by rapeseed displacement in a graduated chamber after cooling for two hours at the room temperature.

\section{Preparation of white salted noodles}

White salted noodles were prepared with $34 \%$ water absorption percent of noodle dough according to the methods described by Park et al. (2002). The procedure of noodle making was as follows: $100 \mathrm{~g}$ of flour $(14.0 \%$ moisture basis) was mixed to $34 \%$ absorption with $6 \%$ sodium chloride solution using a pin mixer (National Mfg., USA) for $4 \mathrm{~min}$ with the head speed of $86 \mathrm{rpm}$. Dough was passed through the rollers of a noodle machine (Ohtake Noodle Machine Mfg., Japan) at $8 \mathrm{rpm}$ and $3 \mathrm{~mm}$ gap; dough was folded and put through the sheeting rollers. The folding and sheeting were repeated twice. The dough sheet was rested for $1 \mathrm{hr}$ and then put through the sheeting rollers three times at progressively decreasing gaps of 2.40, 1.85 and $1.30 \mathrm{~mm}$. A piece of noodle sheet was placed in plastic bags for determination of color. Lightness of the dough sheet was measured by Minolta CM-2002 (Minolta Camera Co., Japan) with $11 \mathrm{~mm}$ measurement aperture. The rest of the dough sheet was cut through no. 12 cutting rolls into strips about $30 \mathrm{~cm}$ in length. The rest of the dough sheet was cut through No. 12 cutting rollers into noodle strands of about $30 \mathrm{~cm}$ in length, with cross section of $0.3 \times 0.2 \mathrm{~cm}$.

\section{Textural properties of cooked noodles}

Raw noodles $(20 \mathrm{~g})$ were cooked at the determined cooking time in $500 \mathrm{ml}$ of boiling distilled water for $18 \mathrm{~min}$ and then rinsed with cold water. Two replicates of cooked noodles were evaluated by texture profile analysis (TPA) using TA-XT2 Texture Analyser (Stable Micro Systems, England) within 5 min after cooking. One set of five strands of cooked 
Table 1. Released year, pedigree, growth habit, heading date, maturing date and yield of 26 Korean wheat cultivars

\begin{tabular}{|c|c|c|c|c|c|c|c|}
\hline Cultivar & $\begin{array}{l}\text { Released } \\
\text { Year }\end{array}$ & Pedigee & $\begin{array}{c}\text { Vernaliza- } \\
\text { tion } \\
\text { (I-VII) }\end{array}$ & $\begin{array}{c}\text { Heading } \\
\text { date } \\
\text { (M.D) }\end{array}$ & $\begin{array}{c}\text { Maturing } \\
\text { date } \\
\text { (M.D) }\end{array}$ & $\begin{array}{l}\text { Culm } \\
\text { length } \\
(\mathrm{Cm})\end{array}$ & $\begin{array}{c}\text { Yield } \\
\text { (MT/ha) }\end{array}$ \\
\hline $\mathrm{Ol}$ & 1976 & Norin72/Norin12 & III & 5.5 & 6.13 & 85 & 3.84 \\
\hline Gereu & 1980 & Strampelli/69D-3607//Chokwang & III & 5.2 & 6.9 & 75 & 3.93 \\
\hline Dahong & 1979 & Norin72/Wonkwang & III & 4.28 & 6.8 & 74 & 4.46 \\
\hline Chungkye & 1979 & Norin4/Sharbatisonora & IV & 4.29 & 6.8 & 71 & 4.51 \\
\hline Eunpa & 1982 & Chukoku81/3/Tob-CNO//Yuksung3/Suwon 185 & III & 5.1 & 6.11 & 76 & 3.95 \\
\hline Tapdong & 1986 & Chukoku81//Suwon158/Toropi & IV & 5.3 & 6.11 & 62 & 4.70 \\
\hline Namhae & 1988 & Ol/Calidad & III & 5.2 & 6.11 & 81 & 5.41 \\
\hline Uri & 1992 & Geuru/Ol & III & 4.27 & 6.7 & 79 & 5.29 \\
\hline Olgeuru & 1994 & Geuru/Chokwang//Nishigai143 & III & 4.26 & 6.8 & 80 & 4.77 \\
\hline Alchan & 1995 & Suwon210/TapdongAlchan, Anbaek & III & 4.30 & 6.11 & 68 & 4.89 \\
\hline Gobun & 1996 & Eunpa/Tapdong//Eunpa/Shannung6521 & III & 4.30 & 6.11 & 72 & 4.78 \\
\hline Keumkang & 1997 & Geuru/Kanto75//Eunpa & III & 4.28 & 6.9 & 73 & 4.22 \\
\hline Seodun & 1997 & Geuru/Genaro81 & III & 4.29 & 6.9 & 71 & 4.85 \\
\hline Saeol & 1997 & Sirogane//Norin43/Sonalika & II & 4.27 & 6.8 & 66 & 5.32 \\
\hline Jinpoom & 1998 & Geuru/Genaro81 & III & 5.1 & 6.11 & 75 & 5.30 \\
\hline Milsung & 1998 & Sirogane//Norin43/Sonalika & II & 4.27 & 5.28 & 70 & 5.24 \\
\hline Joeun & 2000 & Eunpa/Suwon242 & III & 4.21 & 5.29 & 74 & 4.14 \\
\hline Anbaek & 2001 & Sae/Geuru & IV & 4.30 & 6.8 & 70 & 5.42 \\
\hline Jopoom & 2001 & Kanto75//OR8500494P/Bezostaya & III & 4.20 & 6.1 & 64 & 4.54 \\
\hline Jonong & 2003 & Suwon234/SW80199 & III & 4.17 & 5.30 & 67 & 4.65 \\
\hline Jokyung & 2004 & Seri82/Keumkang & II & 4.19 & 6.2 & 81 & 5.19 \\
\hline Younbaek & 2005 & Keumkang/Tapdong & III & 4.23 & 6.4 & 77 & 6.05 \\
\hline Baekjoong & 2007 & Keumkang/Olgeuru & II & 4.29 & 6.7 & 77 & 5.35 \\
\hline Jeokjoong & 2007 & Keumkang/Tapdong & II & 4.28 & 6.7 & 78 & 5.33 \\
\hline Sukang & 2008 & Suwon266/Asakaje & III & 4.28 & 6.8 & 90 & 4.72 \\
\hline Hanbaek & 2008 & Shann7859/Keumkang//Guamuehill & IV & 4.27 & 6.8 & 89 & 5.05 \\
\hline
\end{tabular}

noodles was placed parallel on a flat metal plate and compressed crosswise twice to $70 \%$ of their original height using a $3.175 \mathrm{~mm}$ metal blade at the speed of $1.0 \mathrm{~mm} / \mathrm{sec}$. From force-time curves of the TPA, hardness, springiness and cohesiveness were determined according to the description of Park et al. (2002).

\section{Cookie baking}

The cookie formula and baking procedures were followed as described by Finney et al. (1950) in micro method III. Baked cookies were rested for two hours at the room temperature and their diameter was measured.

\section{Statistical analysis}

Statistical analysis of data was performed by SAS software (SAS Institute, NC, USA) using Fisher's least significant difference procedure (LSD), analysis of variance (ANOVA) and Pearson correlation coefficient. Differences were considered to be significant at $P<0.05$, unless otherwise specified. All data were determined at least in duplicate and all were averaged.

\section{Results}

Grain characteristics and milling performances

Table 1 shows pedigree, growth habit, heading date, maturing date and yield of 26 Korean wheat cultivars. Based on the pedigree of Korean wheat cultivars, germplasm from Japan and international maize and wheat improvement centre (CIMMYT) has mainly contributed to early maturation and increasing grain yield. Korean wheat cultivars developed in 2000s showed earlier heading and maturation date and higher grain yield than cultivars developed in 1980s and 1990s although there was no differences in growth habit and length. Nine Korean wheat cultivars (Chungkye, Dahong, Jonong, Milseong, Namhae, Ol, Olgeuru, Saeol, Uri and Younbaek) showed Pina-Dla/Pinb-Dla genotype (Table 2). Fourteen cultivars had Pina-Dla/Pina-D1b allele

Table 2. Classification of Korean wheat cultivars with respect to the puroindolines genotypes

\begin{tabular}{lcl}
\hline \hline Genotype & $\begin{array}{c}\text { No. of } \\
\text { line }\end{array}$ & \multicolumn{1}{c}{ Korean wheat cultivar } \\
\hline $\begin{array}{l}\text { Pina-Dla } \\
\text { Pinb-Dla }\end{array}$ & 9 & $\begin{array}{l}\text { Chungkye, Dahong, Jonong, Milseoung, Namhae, } \\
\text { Ol, Olgeuru, Saeol, Uri }\end{array}$ \\
\hline $\begin{array}{l}\text { Pina-Dla } \\
\text { Pinb-D1b }\end{array}$ & 14 & $\begin{array}{l}\text { Alchan, Anbaek, Baekjoong, Eunpa, Geuru, } \\
\text { Gobun, Hanbaek, Jeokjoong, Jinpoom, Jokyung, } \\
\text { Jopoom, Keumkang, Seodun, Tapdong }\end{array}$ \\
\hline Pina-Dlb & 3 & Joeun, Sukang, Younbaek \\
Pinb-Dla & &
\end{tabular}


A

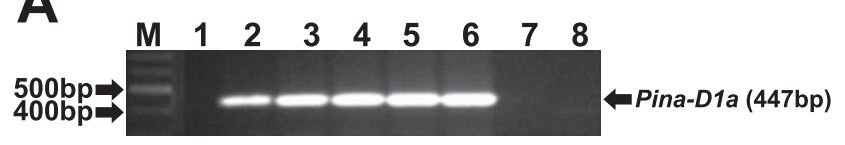

B

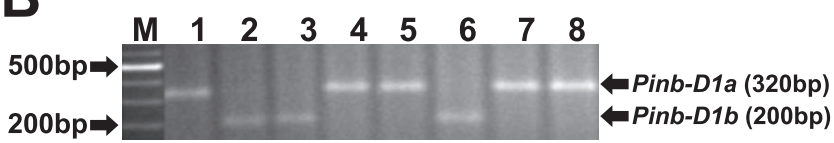

Fig. 1. Agarose gel electrophoresis of PCR amplified Pina-D1 allele (A) and Pinb-D1 (B) cut with BsBrI of Korean wheat cultivars. M, molecular size marker; 1, Jokyung; 2, Geuru; 3, Keumkang; 4, Uri; 5, Jonong; 6, Tapdong; 7, Joeun; 8, Younbaek.

and three cultivars (Joeun, Sukang and Younbaek) carried Pina-D1b/Pinb-Dla allele. Pina-Dla allele was 447 bp in agarose gel electrophoresis of PCR, but no product was found in Pina-D1b (Fig. 1A). Pinb-Dla and Pinb-D1b showed $320 \mathrm{bp}$ and $200 \mathrm{bp}$, respectively after restriction with BsrBI of PCR products (447 bp) of Pinb-D1 allele (Fig. 1B).

Table 3 summarizes grain characteristics, milling performances, physico-chemical properties of wheat flour, dough rheology and end-use quality of Korean wheat flours with different puroindoline genotypes. Korean wheats carrying Pina-Dla/Pinb-Dla showed lower thousand kernel weight, hardness index of grain and flour yield $(38.83 \mathrm{~g}, 31.73$ and $62.20 \%$, respectively) than wheats with Pina-Dla/Pinb-D1b (43.82 g, 64.91 and 69.54\%, respectively) and Pina-D1b/ Pinb-D1a (39.06 g, 67.50 and 71.07\%, respectively). However, there were no significant differences in grain characteristics and milling performances between Pina-D1b/ Pinb-Dla and Pina-Dla/Pinb-D1b genotypes. No significant differences in test weight and the proportion of break flour were found among puroindoline genotypes. In Korean wheat cultivars with all different puroindoline genotypes, flour yield was positively correlated with 1000 kernel weight $(\mathrm{r}=0.474, P<0.05)$ and hardness index $(\mathrm{r}=0.597$, $P<0.001$, Fig. 2A). Hardness index of grain was positively correlated with test weight $(\mathrm{r}=0.443, P<0.05)$ and negatively correlated with the proportion of break flour $(\mathrm{r}=-0.444$, $P<0.05)$. In Korean wheats with Pina-D1b/Pinb-Dla and Pina-Dla/Pinb-D1b, flour yield was negatively correlated with test weight $(\mathrm{r}=-0.528, P<0.05$, Fig. $3 \mathrm{~A})$ and positively correlated with the proportion of break flour $(\mathrm{r}=0.575$, $P<0.05$, Fig. 3B).

\section{Physico-chemical properties and dough rheology}

In Korean wheats with Pina-D1a/Pina-D1b allele, ash and protein content, SDS-sedimentation volume, optimum water absorption and mixing time of mixograph were higher than those of Pina-Dla/Pinb-Dla while average particle size of wheat flour and lightness of flour were lower than those of Pina-Dla/Pinb-Dla (Table 3). But there were no significant differences in these properties between Pina-
Table 3. Differences in grain characteristics, milling performances, physico-chemical properties of flour, dough rheology and end-use quality in Korean wheat cultivars with all different puroindoline genotypes using pair-wise $t$-test

\begin{tabular}{|c|c|c|c|}
\hline \multirow[b]{2}{*}{ Characteristics } & \multicolumn{3}{|c|}{ Allele } \\
\hline & $\begin{array}{l}\text { Pina-Dla } \\
\text { Pinb-Dla }\end{array}$ & $\begin{array}{l}\text { Pina-Dla } \\
\text { Pinb-Dlb }\end{array}$ & $\begin{array}{l}\text { Pina-D1b } \\
\text { Pinb-D1a }\end{array}$ \\
\hline Number of cultivar & 9 & 14 & 3 \\
\hline \multicolumn{4}{|l|}{ Grain characteristics } \\
\hline Test weight (g) & $811.67 \mathrm{a}^{a}$ & $822.57 a$ & $829.50 \mathrm{a}$ \\
\hline 1000-kernel weight (g) & $38.83 b$ & $43.82 \mathrm{a}$ & $39.06 \mathrm{ab}$ \\
\hline Hardness index & $31.73 b$ & $64.91 \mathrm{a}$ & $67.50 \mathrm{a}$ \\
\hline \multicolumn{4}{|l|}{ Milling performances } \\
\hline Flour yield (\%) & $62.20 \mathrm{~b}$ & $69.54 \mathrm{a}$ & $71.07 \mathrm{a}$ \\
\hline Proportion of break flour (\%) & $29.40 \mathrm{a}$ & $26.99 \mathrm{a}$ & $27.98 \mathrm{a}$ \\
\hline \multicolumn{4}{|l|}{ Physico-chemical properties of flour } \\
\hline Average particle size $(\mu \mathrm{m})$ & $64.26 \mathrm{~b}$ & $86.72 \mathrm{a}$ & $96.62 \mathrm{a}$ \\
\hline Ash $(\%)$ & $0.46 \mathrm{~b}$ & $0.51 \mathrm{a}$ & $0.57 \mathrm{a}$ \\
\hline Damaged starch $(\%)$ & $2.08 \mathrm{c}$ & $3.50 \mathrm{~b}$ & $3.81 \mathrm{a}$ \\
\hline Water retention capacity $(\%)$ & $65.18 \mathrm{c}$ & $70.41 b$ & $73.95 \mathrm{a}$ \\
\hline Lightness of flour & $90.73 \mathrm{a}$ & $89.22 b$ & $88.99 b$ \\
\hline Protein $(\%)$ & $10.36 \mathrm{~b}$ & $11.39 \mathrm{ab}$ & $12.81 \mathrm{a}$ \\
\hline Amylose $(\%)$ & $25.42 \mathrm{a}$ & $25.03 \mathrm{a}$ & $24.59 \mathrm{a}$ \\
\hline SDS-sedimentation volume $(\mathrm{ml})$ & $29.72 b$ & $47.14 \mathrm{a}$ & $45.17 \mathrm{a}$ \\
\hline \multicolumn{4}{|l|}{ Dough rheology } \\
\hline Absorption of mixograph (\%) & $57.33 b$ & $59.43 \mathrm{a}$ & $59.67 \mathrm{a}$ \\
\hline Mixing time of mixograph (min) & $2.99 \mathrm{~b}$ & $3.70 \mathrm{a}$ & $3.22 \mathrm{a}$ \\
\hline Maximum height of dough (mm) & $29.93 \mathrm{a}$ & $35.00 \mathrm{a}$ & $32.85 \mathrm{a}$ \\
\hline \multicolumn{4}{|l|}{ End-use qualities } \\
\hline Loaf volume (ml) & $793.89 a$ & $801.43 \mathrm{a}$ & $790.83 a$ \\
\hline Thickness of noodle dough sheet (mm) & $1.77 \mathrm{~b}$ & $1.85 \mathrm{a}$ & $1.91 \mathrm{a}$ \\
\hline Lightness of noodle dough sheet & $83.47 \mathrm{a}$ & $82.14 \mathrm{a}$ & $81.42 \mathrm{a}$ \\
\hline Hardness of cooked noodles $(\mathrm{N})$ & $4.64 \mathrm{a}$ & $5.13 \mathrm{a}$ & $4.96 \mathrm{a}$ \\
\hline Springiness of cooked noodles (Ratio) & $0.92 \mathrm{a}$ & $0.93 \mathrm{a}$ & $0.93 \mathrm{a}$ \\
\hline Cohesiveness of cooked noodles (Ratio) & $0.63 \mathrm{a}$ & $0.63 \mathrm{a}$ & $0.63 \mathrm{a}$ \\
\hline Cookie diameter (mm) & $80.84 a$ & $76.56 b$ & $76.64 b$ \\
\hline
\end{tabular}

${ }^{a}$ Values followed by same letters within same characteristics are not significantly different at $P<0.05$.

D1b/Pinb-Dla and Pina-Dla/Pinb-D1b. Damaged starch and water retention capacity of Pina-D1b/Pinb-D1a were higher than those of other genotypes and Pina-Dla/Pinb$D 1 b$ showed higher values in these properties than PinaDla/Pinb-Dla. There were no significant differences in amylose content and maximum height during dough development among puroindoline genotypes.

In Korean wheat cultivars with all different puroindoline genotypes, average particle size of flour was positively correlated with flour yield $(\mathrm{r}=0.663, P<0.001$, Fig. 2B) and damaged starch content $(\mathrm{r}=0.803, P<0.001$, Fig. $2 \mathrm{C})$. Average particle size of flour was also positively correlated with ash and protein content, SDS-sedimentation volume, optimum water absorption of mixograph and negatively correlated with lightness of wheat flour. Damaged starch content was positively correlated with hardness index of grain, flour yield, and water retention capacity. Lightness of wheat flour was negatively correlated with damaged starch $(\mathrm{r}=-0.791, P<0.001$, Fig. $2 \mathrm{D})$ and water retention capacity 

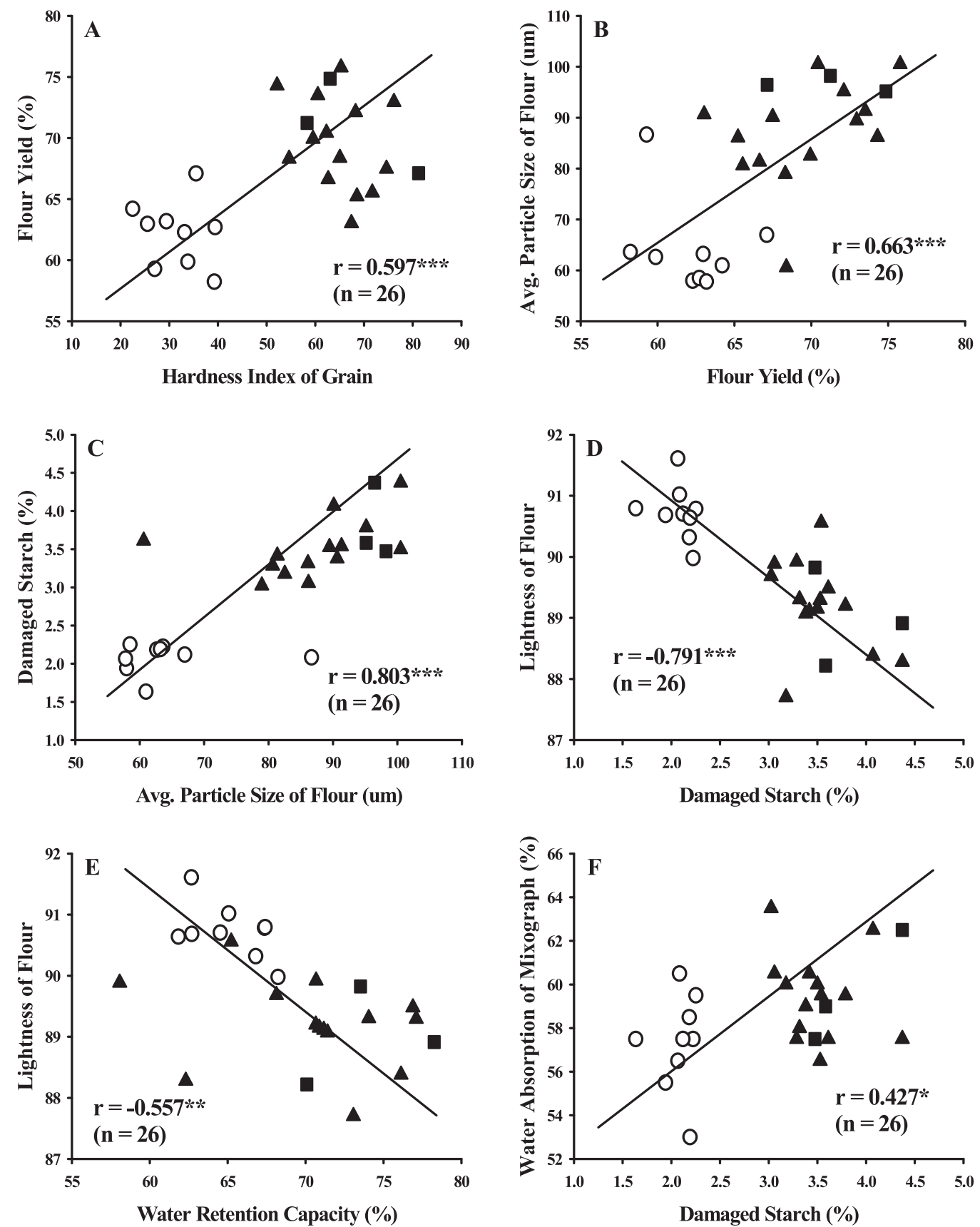

Fig. 2. The relationships between grain characteristics and physical properties of Korean wheat flours with all different puroindoline genotypes. A, hardness index of grain and flour yield; B, flour yield and average of particle size of flour; C, average particle size of flour and damaged starch; $\mathrm{D}$, damaged starch and water retention capacity; E, damaged starch and lightness of flour; F, water retention capacity and lightness of flour. $\bigcirc$; Korean wheats with Pina-Dla/Pinb-Dla, $\mathbf{\Delta}$; Korean wheats with Pina-Dla/Pinb-D1b, $\mathbf{\square}$; Korean wheats with Pina-D1b/Pinb-Dla.

(r $=-0.557, P<0.05$, Fig. 2E). SDS-sedimentation volume was positively correlated with mixing time of mixograph and maximum height during dough development. Optimum water absorption of mixograph was negatively correlated with hardness index of grain and the proportion of break flour and positively correlated with average particle size of flour, and protein and damaged starch content $(\mathrm{r}=0.427$, $P<0.05$, Fig. 2F). There were no significant relationships between mixing time of mixograph and maximum height, grain characteritcs, milling performances and physicochemical properties of wheat flour.

In Korean wheat cultivars with Pina-Dla/Pinb-D1b and Pina-D1b/Pinb-Dla, hardness index was positively correlated with damaged starch $(\mathrm{r}=0.637, P<0.01$, Fig. 3C) and water retention capacity $(\mathrm{r}=0.668, P<0.01$, Fig. $3 \mathrm{D})$ and water retention capacity was negatively correlated with 1000 kernel weight $(\mathrm{r}=-0.559, P<0.05$, Fig. $3 \mathrm{E})$, flour yield ( $\mathrm{r}=-0.516, P<0.05$, Fig. $3 \mathrm{~F})$ and maximum height during 

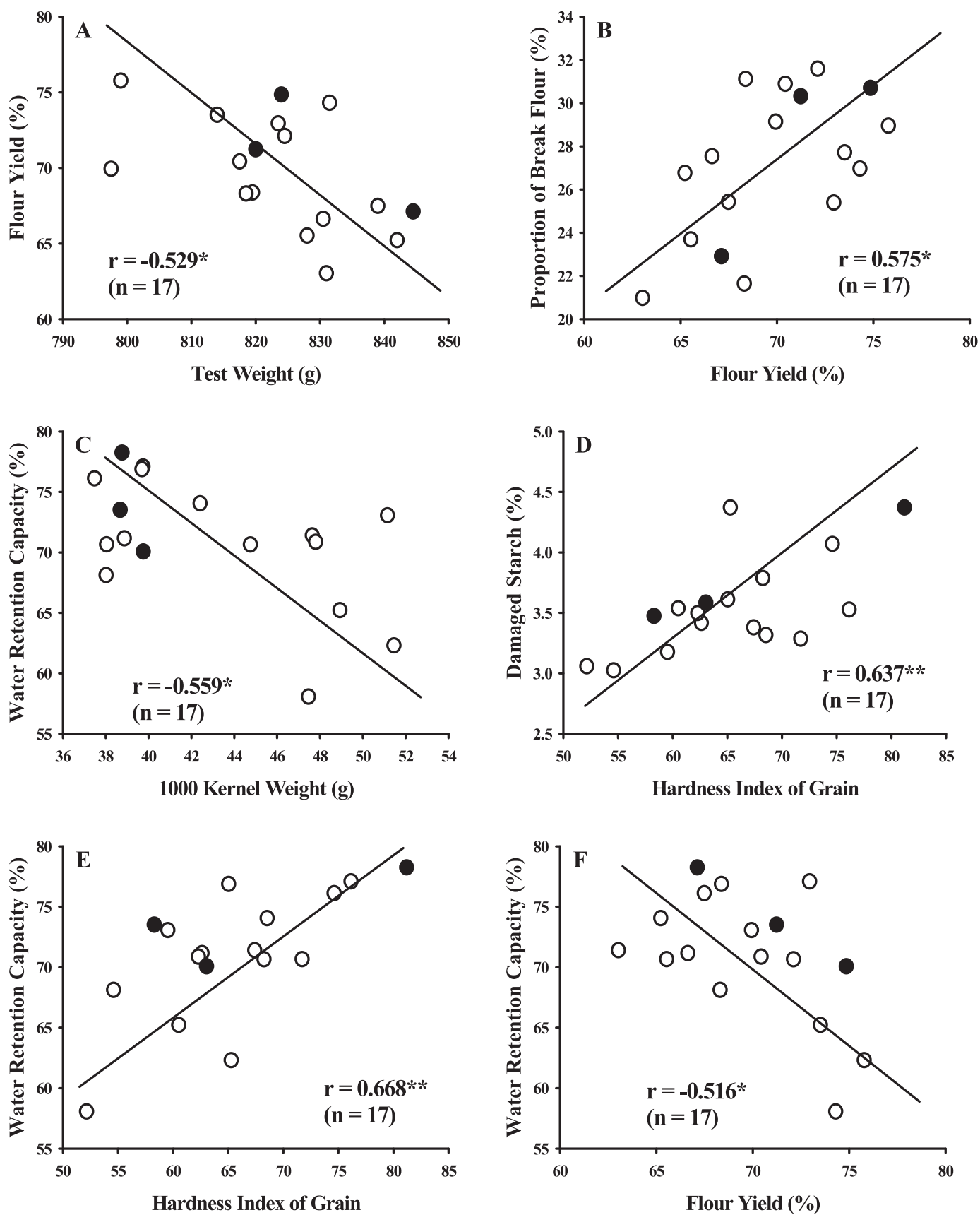

Fig. 3. The relationships between grain characteristics and physical properties of Korean wheat flours with Pina-Dla/Pinb-D1b and Pina-D1b/ Pinb-Dla. A, test weight and flour yield; B, 1000 kernel weight and water retention capacity; C, hardness index and damaged starch; D, hardness index and water retention capacity; E, flour yield and proportion of break flour; F, flour yield and water retention capacity. $\bigcirc$; Korean wheats with Pina-Dla/Pina-Dlb, O; Korean wheats with Pinb-Dla/Pinb-Dla.

dough development. There was no significant correlation between rheological properties, grain characteristics, milling performances and physico-chemical properties, although maximum height during dough development was positively correlated with SDS-sedimentation volume and mixing time of mixograph.

\section{End-use qualities}

Pina-Dla/Pinb-Dla showed lower thickness of noodle dough sheet and larger cookie diameter than Pina-Dla/ Pinb-D1b and Pina-D1b/Pinb-Dla. There were no significant differences in these properties between Pina-DIb/Pinb$D 1 a$ and Pina-Dla/Pinb-D1b. No significant differences were found in loaf volume of bread, lightness of noodle dough sheet and texture of cooked noodles among puroindoline genotypes.

Table 4 shows the relationships among grain characteristics, milling performances, physico-chemical properties and 
Table 4. Correlation coefficients among grain characteristics, milling performances, physico-chemical properties and end-use qualities of Korean wheat cultivars with all different puroindoline genotypes

\begin{tabular}{|c|c|c|c|c|c|c|c|}
\hline \multirow{4}{*}{ Parameters } & \multicolumn{7}{|c|}{ End-use quality } \\
\hline & \multirow{3}{*}{$\begin{array}{c}\text { Bread loaf } \\
\text { volume }\end{array}$} & \multicolumn{5}{|c|}{ White salted noodles } & \multirow{3}{*}{$\begin{array}{c}\text { Cookie } \\
\text { diameter }\end{array}$} \\
\hline & & \multicolumn{2}{|c|}{ Dough sheet } & \multicolumn{3}{|c|}{ Texture of cooked noodles } & \\
\hline & & Thickness & Lightness & Hardness & Springiness & Cohesiveness & \\
\hline \multicolumn{8}{|l|}{ Grain characteristics } \\
\hline Test weight & -0.038 & $0.532 * * a$ & -0.381 & 0.360 & -0.144 & -0.005 & -0.298 \\
\hline 1000-kernel weight & 0.194 & 0.199 & -0.331 & 0.120 & 0.169 & 0.378 & -0.330 \\
\hline Hardness index & 0.004 & $0.640 * * *$ & $-0.395^{*}$ & 0.252 & -0.028 & 0.185 & $-0.731 * * *$ \\
\hline \multicolumn{8}{|l|}{ Milling performances } \\
\hline Flour yield & -0.030 & $0.507 *$ & -0.042 & -0.109 & 0.225 & 0.355 & $-0.517 * *$ \\
\hline Proportion of break flour & -0.249 & -0.380 & $0.389 *$ & $-0.495 * * *$ & 0.068 & -0.240 & $0.390 *$ \\
\hline \multicolumn{8}{|c|}{ Physico-chemical properties of flour } \\
\hline Average particle size & 0.091 & $0.636 * * *$ & $-0.487^{*}$ & 0.293 & 0.081 & $0.441 *$ & $-0.530 * *$ \\
\hline Ash & 0.051 & $0.480 *$ & $-0.640 * * *$ & $0.535 * *$ & -0.285 & -0.125 & -0.305 \\
\hline Damaged starch & 0.036 & $0.706 * * *$ & $-0.404 *$ & 0.205 & 0.074 & 0.288 & $-0.747 * * *$ \\
\hline Water retention capacity & -0.287 & 0.322 & $-0.401 *$ & 0.236 & -0.201 & -0.221 & $-0.413^{*}$ \\
\hline Lightness of flour & 0.116 & $-0.651 * * *$ & $0.528 * *$ & -0.197 & -0.041 & -0.253 & $0.619 * * *$ \\
\hline Protein & 0.249 & $0.725 * * *$ & $-0.879 * * *$ & $0.687 * * *$ & 0.073 & $0.416^{*}$ & $-0.434^{*}$ \\
\hline Amylose & -0.093 & -0.363 & $0.547 * *$ & $-0.456^{*}$ & -0.152 & -0.362 & 0.212 \\
\hline SDS-sedimentation volume & 0.076 & $0.469^{*}$ & -0.126 & 0.136 & 0.324 & 0.210 & $-0.659 * * *$ \\
\hline \multicolumn{8}{|l|}{ Dough rheology } \\
\hline Absorption of mixograph & $0.442 *$ & $0.571 * *$ & $-0.727 * * *$ & $0.769 * * *$ & 0.181 & $0.608 * * *$ & $-0.449 *$ \\
\hline Mixing time of mixograph & $0.493 *$ & 0.183 & 0.017 & 0.211 & 0.264 & 0.198 & -0.351 \\
\hline Maximum height of dough & $0.589 * *$ & 0.115 & 0.072 & 0.167 & 0.212 & 0.286 & -0.196 \\
\hline
\end{tabular}

$a *$ indicates significance at 0.05 level, $* *$ at 0.01 level, and $* * *$ at 0.001 level.

end-use qualities of Korean wheat cultivars with all different puroindoline genotypes. Loaf volume of bread was positively correlated with mixograph properties and maximum height of dough. Thickness of noodle dough sheet was positively correlated with hardness index, flour yield, average particle size, damaged starch and protein content, and optimum water absorption of mixograph in all different puroindoline genotypes. Those properties were negatively correlated with lightness of noodle dough sheet and cookie diameter. Flour yield was positively correlated with thickness of noodle dough sheet and negatively correlated with cookie diameter. The proportion of break flour was positively correlated with lightness of noodle dough sheet and cookie diameter. Protein content and optimum water absorption of mixograph were positively correlated with hardness and cohesiveness of cooked noodles. The proportion of break flour and average particle size were also correlated with those parameters of cooked noodles.

Table 5 shows the relationships among grain characteristics, milling performances, physico-chemical properties and end-use qualities of Korean wheat cultivars with Pina-Dla/ Pinb-D1b and Pina-D1b/Pinb-DIa. Loaf volume of bread was negatively correlated with water retention capacity and positively correlated with mixing time of mixograph and maximum height of dough. Properties of noodle dough sheet were significantly correlated with protein content and optimum water absorption of mixograph. Ash content and light- ness of flour were also correlated with lightness of noodle dough sheet. Hardness of cooked noodles was correlated with flour milling performances, protein content and optimum water absorption of mixograph. Springiness of cooked noodles was positively correlated with flour yield, although springiness showed no significant relationships with grain characteristics, milling performances and physico-chemical properties of wheat flours with all different puroindoline genotypes. Cohesiveness of cooked noodles was correlated with water retention capacity and optimum water absorption of mixograph. Cookie diameter showed no significant relationships with grain characteristics, milling performances and physico-chemical properties of wheat flours.

\section{Discussion}

Most Korean wheat cultivars were shown to have Pina-Dlal Pinb-D1b, which was similar to the genetic variations of CIMMYT lines, North American, Europe, China and Australia (Lillemo and Morris 2000, Morris et al. 2001, Cane et al. 2004, Xia et al. 2005, Chen et al. 2006, Lillemo et al. 2006, Pickering and Bhave 2007). There were no significant differences in grain characteristics and milling performances of Korean wheats with Pina-D1b/Pinb-Dla and Pina-Dla/Pinb-D1b genotypes, although these genotypes showed higher 1000 kernel weight, hardness index and flour yield than Korean wheats with Pina-Dla/Pinb-Dla 
Table 5. Correlation coefficients among grain characteristics, milling performances, physico-chemical properties and end-use qualities of Korean wheat cultivars with Pina-D1b/Pinb-Dla and Pina-Dla/Pinb-D1b

\begin{tabular}{|c|c|c|c|c|c|c|c|}
\hline \multirow{4}{*}{ Parameters } & \multicolumn{7}{|c|}{ End-use quality } \\
\hline & \multirow{3}{*}{$\begin{array}{l}\text { Bread loaf } \\
\text { volume }\end{array}$} & \multicolumn{5}{|c|}{ White salted noodles } & \multirow{3}{*}{$\begin{array}{c}\text { Cookie } \\
\text { diameter }\end{array}$} \\
\hline & & \multicolumn{2}{|c|}{ Dough sheet } & \multicolumn{3}{|c|}{ Texture of cooked noodles } & \\
\hline & & Thickness & Lightness & Hardness & Springiness & Cohesiveness & \\
\hline \multicolumn{8}{|l|}{ Grain characteristics } \\
\hline Test weight & 0.056 & 0.349 & -0.236 & 0.366 & -0.127 & -0.068 & -0.149 \\
\hline 1000-kernel weight & 0.088 & -0.209 & 0.003 & -0.181 & 0.077 & 0.270 & 0.060 \\
\hline Hardness index & -0.292 & 0.223 & -0.110 & 0.013 & -0.152 & -0.364 & -0.433 \\
\hline \multicolumn{8}{|l|}{ Milling performances } \\
\hline Flour yield & -0.094 & 0.024 & 0.448 & $-0.512 *$ & $0.496^{*}$ & 0.145 & -0.008 \\
\hline Proportion of break flour & -0.177 & -0.371 & 0.412 & $-0.573 *$ & 0.283 & -0.119 & 0.362 \\
\hline \multicolumn{8}{|c|}{ Physico-chemical properties of flour } \\
\hline Average of particle size & -0.065 & 0.135 & -0.028 & -0.146 & 0.121 & 0.404 & 0.134 \\
\hline Ash & -0.033 & 0.326 & $-0.557^{*}$ & 0.440 & $-0.533^{*}$ & -0.308 & -0.132 \\
\hline Damaged starch & -0.052 & 0.423 & -0.100 & -0.140 & 0.210 & 0.051 & -0.470 \\
\hline Water retention capacity & $-0.542 * a$ & -0.023 & -0.246 & 0.081 & -0.412 & $-0.581^{*}$ & 0.034 \\
\hline Lightness of flour & 0.264 & -0.368 & $0.517 *$ & 0.010 & -0.199 & -0.125 & 0.210 \\
\hline Protein & 0.157 & $0.712 * *$ & $-0.854 * * *$ & $0.592 *$ & 0.074 & 0.413 & -0.191 \\
\hline Amylose & -0.131 & -0.271 & $0.562 *$ & -0.467 & -0.161 & -0.382 & -0.172 \\
\hline SDS-sedimentation volume & 0.081 & 0.012 & $0.500^{*}$ & -0.164 & 0.414 & -0.050 & -0.293 \\
\hline \multicolumn{8}{|l|}{ Dough rheology } \\
\hline Absorption of mixograph & 0.272 & $0.519^{*}$ & $-0.626^{* *}$ & $0.762 * * *$ & -0.008 & $0.568^{*}$ & -0.014 \\
\hline Mixing time of mixograph & $0.605 * *$ & -0.067 & 0.409 & 0.125 & 0.073 & 0.048 & -0.149 \\
\hline Maximum height of dough & $0.721 * * *$ & -0.135 & 0.408 & 0.019 & 0.135 & 0.205 & 0.061 \\
\hline
\end{tabular}

a* indicates significance at 0.05 level, $* *$ at 0.01 level, and $* * *$ at 0.001 level.

genotypes. Nagamine et al. (2003) reported that Pina-Dla/ Pinb-Db had higher flour yield than Pina-Dla/Pinb-Da in 110 doubled haploid lines, although there was no significant difference in 1000 kernel weight. Hard wheats with PinaDla/Pinb-D1b had significantly higher flour yield, break flour yield and milling score than wheats with Pina-DIb/ Pinb-Dla in recombinant inbred lines of hard red spring wheats (Martin et al. 2001) and Australian wheats (Eagles et $a l$. 2006). However, there was no significant difference in flour yield and proportion of break flour between Pina-Dlal Pinb-DIb and Pina-D1b/Pinb-Dla genotypes in Korean wheats.

Hardness index of SKCS is widely accepted as the standard method to determine the single wheat kernel texture and is the most discriminating measure of the material properties of the wheat endosperm manifested by the action of the $\mathrm{Ha}$ locus (Moris et al. 1999, Osborne and Anderssen 2003). Hardness index was significantly correlated with flour yield and the proportion of break flour in Korean wheats with all puroindoline genotypes, but no significant relationships were found in Korean hard wheats. However, hardness index was negatively correlated with flour yield in hard wheats (Ohm et al. 1998, Martin et al. 2001) and Chinese winter wheats (Zhang et al. 2005) and also negatively correlated with break flour yield in US wheats with various puroindoline genotypes (Bettge and Morris 2000).

Korean wheats with Pina-Dla/Pinb-Dla genotypes showed different physico-chemical properties including particle size of wheat flours, flour color, ash, protein and damaged starch content, water retention capacity, SDSsedimentation volume and mixograph properties from Korean wheats with Pina-D1b/Pinb-Dla and Pina-Dlal Pinb-Dlb genotypes. Soft wheats showed lower average particle size of flour, ash and damaged starch content, and higher lightness of flour than hard wheats in doubled haploid lines from Japan and US wheats with different puroindoline genotypes (Bettege and Morris 2000, Nagamine et al. 2003). Korean wheats with Pina-Dlb/Pinb-Dla had greater starch damage in milling processing than Pina-Dla/Pinb$D 1 b$ genotypes and the damage could have an effect on water absorption of rheological properties, which are in agreement with previous results (Cane et al. 2004, Eagles et al. 2006, Chen et al. 2007). There were no significant differences in any other physico-chemical properties and mixing properties between those Korean wheat cultivars. In hard red spring wheats and cultivated wheats in China, Pina-Dla/ Pinb-DIb had lower ash content and brighter flour color than Pina-D1b/Pinb-Dla but there was no difference in mixing time of mixograph (Martin et al. 2001, Chen et al. 2007). In near-isogenic lines of puroindolines, no difference was found in ash content and water retention capacity between Pina-Dla/Pinb-Dlb and Pina-DIb/Pinb-Dla, however, the former had lower damaged starch content and brighter color than the latter (Ma et al. 2009). 
In Korean wheats, physical properties of flour including average particle size of flour, ash and damaged starch content, water retention capacity and lightness of flour showed significant relationships with hardness index or flour yield. There were also significant relationships between these physical properties in Korean wheats. Those results are in good agreement with previous results (Bettege and Morris 2000, Morgan et al. 2000, Martin et al. 2001, Nagamine et al. 2003, Zhang et al. 2005, Chen et al. 2007). Therefore, grain characteristics, especially hardness index of grain, could have influence on the milling performance and physical properties of Korean wheat flours.

Pina-D1b/Pinb-Dla genotypes had better bread quality in pan bread and Chinese steam bread than Pina-Dla/PinbD1b (Martin et al. 2001, Chen et al. 2007). However, there were no significant differences in bread volume among Korean wheats, although bread volume showed significant relationships with dough rheological properties. It should be considered to increase the frequency of Pina-D1b/Pinb-Dla genotypes in Korean wheat cultivars with strong gluten strength to improve bread-baking quality. In noodle making properties and texture of cooked noodles from Korean wheats, no significant differences were found among puroindoline genotypes except for thickness of noodle dough sheet. Ma et al. (2009) reported that there were no significant differences in qualities for Chinese raw white noodles between Pina-D1b/Pinb-Dla and Pina-Dla/Pinb-D1b. They also proposed that Pina-Dla/Pinb-Dle and Pina-Dla/Pinb-D1g had slightly superior noodle qualities in comparison with other genotypes. However, Chen et al. (2007) reported that Pina-D1b/Pinb-Dla also had higher noodle score for dry white Chinese noodles than Pina-Dla/Pinb-D1b and PinaDla/Pinb-Dla. Therefore, it should be considered to introduce various puroindoline genotypes such as Pina-Dla/ Pinb-Dle and Pina-Dla/Pinb-Dlg to improve noodle quality. Cookie diameter was influenced by hardness index, milling performances and physico-chemical properties, and especially by the particle size of flour, damaged starch content and SDS-sedimentation volume. Pina-Dla/Pinb-Dla had larger cookie diameter than other genotypes, which is in agreement with the report of Bettge and Morris (2000).

Grain hardness, flour yield and physical properties of flour were mainly associated with the genetic variations of puroindolines in Korean wheat cultivars. Most of the Korean wheat cultivars developed in the 2000s showed hard wheat type in puroindoline alleles because of higher flour yield than soft wheat types. Korean wheat cultivars carrying Pina$D 1 b$ or $P i n b-D 1 b$ alleles showed higher grain weight, flour yield, average of particle size of flour, damaged starch content and water absorption than Korean wheats with Pina$D 1 a$ and Pinb-Dla alleles. However, end-use qualities have not been affected by the allelic variations in puroindolines, albeit significant differences were found in dough rheological properties. Therefore, it is necessary to introduce various puroindoline genotypes, like Pinb-Dle and Pinb-D1g alleles and increase the frequency of Pina-DIb allele of Korean wheats to improve flour yield and qualities of bread and noodles to overcome the narrow genetic background in glutenin and puroindolines. In addition to puroindolines, factors related to starch pasting properties and discolorations, such as $W x-1, P p o-2$ and $P s y-1$ alleles, should be investigated to improve noodle processing and textural properties of cooked noodles. It is necessary to introduce diverse $G l u$-3 alleles in Korean wheat cultivars with Glu-D1d alleles to improve dough strength for better bread-baking qualities.

\section{Literature Cited}

American Association of Cereal Chemists (2000) Approved Methods of the AACC. 10th ed. The Association, St. Paul, MN.

Baik,B.-K., Z.Czuchajowska and Y.Pomeranz (1994) An SDS-FY test to evaluate quality of wheat for oriental noodles. J. Cereal Sci. 19: 191-201.

Barlow,K.K., M.S.Buttrose, D.H.Simmonds and M.Vesk (1973) The nature of the starch-protein interface in wheat endosperm. Cereal Chem. 50: 443-454.

Bettge, A.D. and C.F.Morris (2000) Relationships among grain hardness, pentosan fractions, and end-use quality of wheat. Cereal Chem. 77: 241-247.

Blochet,J. E., C.Chevalier, E.Forest, E.Pebay-Peyroula, M.F.Gautier, P.Joudrier, M.Pezolet and D.Marion (1993) Complete amino-acid sequence of puroindoline, a new basic and cystine-rich protein with a unique tryptophan-rich domain, isolated from wheat endosperm by Triton X-114 phase partitioning. FEBS Lett. 329: 336-340.

Cane,K., M.Spackman and H.A.Eagles (2004) Puroindoline genes and their effects on grains quality traits in southern Australian wheat cultivars. Aust. J. Agric. Res. 55: 89-95.

Chen,F., Z.H.He, X.C.Xia, L.Q.Xia, X.Y.Zhang, M.Lillemo and C.F.Morris (2006) Molecular and biochemical characterisation of puroindoline $\mathrm{a}$ and $\mathrm{b}$ alleles in Chinese landraces and historical cultivars. Theor. Appl. Genet. 112: 400-409.

Chen,F., Z.He, D.Chen, C.Zhang, Y.Zhang and X.Xia (2007) Influence of puroindoline alleles on milling performance and qualities of Chinese noodles, steamed bread and pan bread in spring wheats. J. Cereal Sci. 45: 59-66.

Czuchajowska,Z. and Y.Pomeranz (1993) Gas formation and gas retention. I. The system and methodology. Cereal Foods World 38: 499-503.

Eagles, H.A., K. Cane, R.F. Eastwood, G.J.Hollamby, H. Kuchel, P.J.Martin and G.B.Cornish (2006) Contributions of glutenin and puroindoline genes to grain quality traits in southern Australian wheat breeding programs. Aust. J. Agric. Res. 57: 179-186.

Finney, K.F. (1984) An optimized, straight-dough, bread-making method after 44 years. Cereal Chem. 25: 20-27.

Finney, K.F., V.H.Morris and W.T.Yamazaki (1950) Micro versus macro cookie baking procedures for evaluating the cookie quality of wheat varieties. Cereal Chem. 27: 42-49.

Gautier,M.-F., M.-E.Aleman, A.Guirano, D.Marion and P.Joudrier (1994) Triticum aestivum puroindolines, two basic cysteine-rich seed proteins: cDNA sequence analysis and developmental gene expression. Plant Mol. Biol. 25: 43-57.

Gibson, T.S., H.A.Qalla and B.V.McCleary (1992) An improved method for the measurement of starch damage in wheat flour. J. Cereal Sci. 15: 15-27.

Giroux, M.J. and C.F.Morris (1997) A glycine to serine change in puroindoline $\mathrm{b}$ is associated with wheat grain hardness and low 
levels of starch-surface friabilin. Theor. Appl. Genet. 95: 857-864.

Giroux, M.J. and C.F.Morris (1998) Wheat grain hardness results from highly conserved mutations in the friabilin components puroindoline a and b. Proc. Natl. Acad. Sci. USA 95: 6262-6266.

Giroux,M.J., L.Talbert, D.K.Habernicht, S.Lanning, A.Hemphill and J.M.Martin (2000) Association of puroindoline sequence type and grain hardness in hard red spring wheat. Crop Sci. 40: 370-374.

Greenwell,P. and J.D.Schofield (1986) A starch granule protein associated with endosperm softness in wheat. Cereal Chem. 63: 379380.

Jolly,C.J., S.Rahman, A.A.Kortt and T.J.V.Higgins (1993) Characterization of the wheat $M_{\mathrm{r}} 15000$ 'grain-softness protein' and analysis of the relationships between its accumulation in the whole seed and grain softness. Theor. Appl. Genet. 86: 589-597.

Lillemo,M. and C.F.Morris (2000) A leucine to proline mutation in puroindoline $\mathrm{b}$ is frequently present in hard wheats from Northern Europe. Theor. Appl. Genet. 100: 1100-1107.

Lillemo,M., F.Chen, X.C.Xia, M.William, R.J.Peña, R.Thretowan and Z.H.He (2006) Puroindoline grain hardness alleles in CIMMYT bread wheat. J. Cereal Sci. 44: 86-92.

Ma,D., Y.Zhang, X.C.Xia, C.F.Morris and Z.H.He (2009) Milling and Chinese raw white noodle qualities of common wheat near-isogenic lines differing in puroindoline b allele. J. Cereal Sci. 50: 126-130.

Martin,J.M., R.C.Frohberg, C.F.Morris, L.E.Talbert and M.J.Giroux (2001) Milling and bread baking traits associated with puroindoline sequence type in hard red spring wheat. Crop Sci. 41: 228-234.

Morgan, B.C., J.E.Dexter and K.R.Preston (2000) Relationship of kernel size to flour water absorption for Canada Western Red Spring wheat. Cereal Chem. 77: 256-292.

Morris, C.F. and S.P.Rose (1996) Wheat. In: Henry, R.J. and P.S Kettlewell (eds.) Cereal Grain Quality, Chapman Hall, UK, pp.354.

Morris,C.F., V.L.DeMacon and M.J.Giroux (1999) Wheat grain hardness among chromosome 5D homozygous recombinant substitution lines using different methods of measurement. Cereal Chem. 76: 249-254.

Morris, C.F., M.Lillemo, M.C.Simeone, M.J.Giroux, S.L.Babb and
K.K.Kidwell (2001) Prevalence of puroindoline grain hardness genotypes among historically significant North American spring and winter wheats. Crop Sci. 41: 218-228.

Morris,C.F. and M.Bhave (2008) Reconcilation of D-genome puroindoline allele designations with current DNA sequence data. J. Cereal Sci. 48: 277-287.

Nagamine,T., T.M.Ikeda, T.Yanagisawa, M.Yanaka and N.Ishikawa (2003) The effects of hardness allele Pinb-D1b on the flour quality of wheat for Japanese white salty noodles. J. Cereal Sci. 37: 337342

Ohm,J.B., O.K.Chung and C.W.Deyoe (1998) Single-kernel characteristics of hard winter wheats in relation to milling and baking quality. Cereal Chem. 75: 156-161.

Osborne,B.G. and R.S.Anderssen (2003) Single-kernel characterization principles and applications. Cereal Chem. 80: 613-622.

Park,C.S. and B.-K.Baik (2002) Flour characteristics related to optimum water absorption of noodle dough for making white salted noodles. Cereal Chem. 79: 867-873.

Pickering, P.A. and M.Bhave (2007) Comprehensive analysis of Australian hard wheat cultivars shows limited puroindoline allele diversity. Plant Sci. 172: 371-379.

Rahman,S., J.C.Jolly, J.H.Skerritt and A.Wallosheck (1994) Cloning of a wheat $15-\mathrm{kDa}$ grain softness protein (GSP). GSP is a mixture of puroindoline-like polypeptides. Eur. J. Biochem. 223: 917-925.

Sourdille,P., M.R.Perretant, P.Charmet, M.F.Leroy, P.Gautier, J.C. Joudrier, J.C.Nelson, M.E.Sorrells and M.Bernard (1996) Linkage between RFLP markers and genes affecting kernel hardness in wheat. Theor. Appl. Genet. 93: 580-586.

Symes,K.J. (1965) The inheritance of grain hardness in wheat as measured by the particle size index. Aust. J. Agric. Res. 16: 113-123.

Xia,L.Q., F.Chen, Z.H.He, X.Chen and C.F.Morris (2005) Occurrence of puroindoline alleles in Chinese winter wheats. Cereal Chem. 82: 38-43.

Zhang,Y., K.Quail, D.C.Mugford and Z.H.He (2005) Milling quality and white salted noodle color of Chinese winter wheat cultivars. Cereal Chem. 52: 633-638. 